\title{
ASFIKSIA PERINATAL SEBAGAI FAKTOR RESIKO GANGGUAN PENDENGARAN PADA ANAK
}

\author{
Sukri Rahman, Hanifatryevi \\ Bagian Ilmu Kesehatan Telinga Hidung Tenggorok-Bedah Kepala Leher \\ Fakultas Kedokteran Universitas Andalas/RS Dr. M. Djamil Padang \\ email : sukri_rahman@yahoo.com
}

\begin{abstract}
Abstrak
Asfiksia adalah keadaan di mana tubuh atau bagian tubuh kekurangan oksigen. Jika kondisi ini terjadi pada bayi baru lahir disebut dengan asfiksia perinatal, yang dapat menimbulkan kerusakan jaringan secara permanen maupun bersifat sementara, salah satunya adalah gangguan pendengaran sensorineural.

Makalah ini akan membahas tentang mekanisme gangguan pendengaran akibat asfiksia, deteksi dini gangguan pendengaran dengan pemeriksaan Brain Evoked Response Auditory (BERA) dan Otoacoustic Emissions (OAE).

Gangguan pendengaran akibat asfiksia dapat terjadi akibat beberapa mekanisme. Kelainan ini terlihat pada gambaran BERA dan OAE, dimana terjadinya peningkatan masalaten dan interval gelombang yang bersifat sementara atau menetap, serta ditemukan gangguan pada fungsi koklea bayi dengan asfiksia perinatal terutama pada frekuensi $1-5 \mathrm{kHz}$ yang terdeteksi pada hari ke tiga sampai hari kelima kelahiran, dan terdapat perbaikan pada usia 1 bulan.
\end{abstract}

Kata Kunci : Asfiksia perinatal, gangguan pendengaran, BERA, OAE

\section{Abstract}

Asphyxia is a condition in which the body or body part to lack of oxygen. If this condition occurs in newborns with perinatal asphyxia is also called, which can cause tissue damage is permanent or temporary. One of that is a sensorineural hearing loss.

This paper will discuss the mechanisms of hearing loss due to asphyxia, early detection of hearing loss with an examination Brain Auditory Evoked Response (BERA) and Otoacoustic Emissions (OAE).

Hearing loss due to asphyxia can occur due to several mechanisms. These abnormalities are seen on the results of BERA and OAE, where an increase in latent period and the interval waves that are temporary or permanent, and found interference with the function of the cochlea infants with perinatal asphyxia, especially at frequency of $1-5 \mathrm{kHz}$ were detected on the third day until the fifth day of birth, and there are improvements to the age of 1 month.

Key word : Perinatal asphyxia, hearing loss, Brain Auditory Evoked Response, Otoacoustic Emissions 


\section{Pendahuluan}

Asfiksia adalah keadaan di mana tubuh atau bagian tubuh kekurangan oksigen. Jika kondisi ini terjadi pada bayi baru lahir disebut juga dengan asfiksia perinatal. Resiko dari asfiksia perinatal mulai dari berbagai derajat gangguan saraf dan motorik sampai menyebabkan kematian. ${ }^{(1-3)}$ Akibat yang ditimbulkan tergantung pada lokasi dan luasnya jaringan yang mengalami kerusakan. ${ }^{(4)}$ Salah satu gejala sisa yang sering terjadi pada asfiksia perinatal adalah gangguan pendengaran sensorineural. ${ }^{(1,2)}$

Prevalensi gangguan pendengaran sedang hingga sangat berat bilateral pada bayi baru lahir adalah 1-6 per 1000 kelahiran, yang mana $10 \%$ nya merupakan gangguan pendengaran yang sangat berat. ${ }^{(6)}$ Kezirian menuliskan prevalensi gangguan pendengaran sebesar 1-3 per 1000 bayi. $^{(7)}$

American Academy of Pediatric Joint Committee tahun 1993 menyatakan asfiksia perinatal merupakan salah satu faktor risiko terjadinya gangguan pendengaran, disamping faktor resiko lainnya seperti riwayat keluarga, kelainan struktur kepala dan leher, infeksi saat hamil, lahir prematur, berat badan lahir rendah, persalinan dengan tindakan, bayi kuning. Anak dengan satu faktor resiko akan memiliki kemungkinan 10 kali lebih besar mengalami gangguan pendengaran dan 63 kali lebih besar jika disertai dua faktor risiko lainnya. ${ }^{(8)}$

Angka kejadianasfiksia perinatal bervariasi di masing-masing negara, sekitar 2 sampai 9 dari setiap 1000 kelahiran hidup. Penelitian di California dari tahun 1991-2000 didapatkan angka kejadian asfiksia perinatal sebesar 4.5 setiap 1000 kelahiran hidup, di British Hospital angka kejadian asfiksia sangat menurun dari 7.7 per 1000 kelahiran hidup pada akhir 1970 menjadi 1.9 per 1000 kelahiran hidup di tahun 1990. Di Swedia angka kejadian asfiksia perinatal berkisar 1,8 sampai 6,9 setiap 1000 kelahiran hidup. ${ }^{(5)}$

Menemukan gangguan pendengaran pada bayi tidak mudah, tanpa program skrining pendengaran gangguan pendengaran baru diketahui pada usia 18 - 24 bulan. ${ }^{(6,7)}$

Tujuan skrining pendengaran bayi baru lahir adalah menemukan gangguan pendengaran sedini mungkin sehingga dapat dilakukan habilitasi segera, menggunakan pemeriksaan elektrofisiologik yang bersifat obyektif, praktis, otomatis dan non invasive. ${ }^{(9)}$

Menurut The Joint Committee on Infant Hearing (JCIH) tahun 2007 terdapat perbaikan dari konsensus yang ada pada tahun 2000, terutama dari target skrining gangguanpendengaran yang awalnya hanya terdiri dari gangguan pendengaran kongenital bilateral, gangguan pendengaran konduktif permanen, gangguan pendengaran sensori unilateral, ditambahkan dengan gangguan pendengaran neural yang salah satu contohnya adalah gangguan pendengaran neuropati audi-tori pada bayi dengan riwayat perawatan di ruang intensif lebih dari 5 hari. Sehingga pada bayi dengan riwayat perawatan di ruang intensif lebih dari 5 hari, pemeriksaan auditory brainstem response (ABR) merupakan skrining awal yang harus dilakukan. ${ }^{(8)}$

\section{Embriologi Telinga Dalam, Anatomi dan Fisiologi Pendengaran}

Embriologi telinga dalam mulai berkembang pada minggu ketiga usia gestasi, dan pada minggu ke 20 pematangan koklea sudah mencapai 
ukuran dan fungsi dewasa yang sudah dapat memberi respons terhadap suara. ${ }^{(10)}$

Labirin terletak pada pars petrosa os temporal yang mengandung organ pendengaran dan keseimbangan. ${ }^{(11,12)}$ Labirin terdiri dari labirin bagian tulang dan labirin bagian membran. Labirin bagian tulang terdiri dari kanalis semisirkularis, vestibulum dan koklea sedangkan labirin bagian membran terdiri dari utrikulus, sakulus, sakus dan duktus endolimfatikus. Antara labirin bagian tulang dan membran terdapat suatu ruangan yang berisi cairan perilimfe yang berasal dari cairan serebrospinalis dan filtrasi dari darah. Didalam labirin bagian membran terdapat cairan endolimfe yang diproduksi oleh stria vaskularis dan diresorbsi pada sakkus endolimfatikus. ${ }^{(12,13)}$

Koklea terdiri dari $23 / 4$ putaran spiral. Dasar spiral menjorok ke telinga tengah sebagai promontory dinding medial telinga tengah. Potongan melintang dari koklea menunjukkan bahwa koklea dibagi menjadi tiga segmen. Dari atas ke bawah adalah skala vestibuli, skala media dan skala timpani. Setiap skala berisi cairan. Pada skala media berisi cairan endolimfe dan pada skala vestibuli dan skala timpani berisi cairan perilimfe. Pertemuan antara perilimfe dari skala vestibuli dan skala timpani pada puncak koklea pada titik yang dikenal sebagai helicontrema. ${ }^{(12,13)}$

Koklea memiliki volume sekitar 0,2 mililiter. Dalam ruang ini terdapat lebih kurang 30.000 sel-sel rambut yang mentransduksi getaran menjadi impuls saraf dan sekitar 19.000 serat saraf yang mengirimkan sinyal ke dan dari otak. ${ }^{(13)}$

Terdapat 2 tipe sel rambut yang terdapat dalam organ corti, yaiti satu baris sel rambut dalam dan 3 baris sel rambut luar. Masing-masing sel ini mempunyai fungsi yang berbeda. Sel rambut dalam mempunyai fungsi utama untuk mentransmisikan sinyal bunyi sampai ke otak. Sembilan puluh lima persen dari serabut saraf pendengaran yang membawa transmisi sinyal bunyi sampai ke otak (serabut afferen) hanya berkontak dengan sel rambut dalam, sehingga sinaps antara sel rambut dalam dengan serabut afferen merupakan relay pertama pada jaras pendengaran. Sel rambut luar menerima sinyal berkisar $5 \%$ dari serabut afferen dan juga berhubungan dengan serabut efferen yang meneruskan umpan balik dari otak ke organ pendengaran. ${ }^{(10)}$

Proses transmisi suara di koklea dimulai dengan energi akustik yang menghasilkan aksi seperti piston dengan landasan tulang stapes pada foramen oval. Energi tersebut akan diteruskan ke perilimfe di skala vestibuli dan menggetarkan membran Reissner dan akan menggetarkan endolimf di skala media, sehingga terjadi pergeseran membran basilaris. Pergeseran membran basilaris membentuk gelombang berjalan dengan amplitudo. Besarnya amplitudo sesuai dengan besar frekuensi rangsangan yang diterima. Membran basilaris lebih kaku pada bagian basal dibandingkan apeks, sehingga perjalanan gelombang bergerak dari basal ke apeks. ${ }^{(10,14,15)}$

Getaran membran basilaris menimbulkan gerak relatif dengan membran tektoria yang merupakan rangsangan mekanik. Rangsangan mekanik ini menyebabkan defleksi stereosilia sel-sel rambut sehingga terjadi pelepasan ion-ion bermuatan listrik. Pada proses ini terjadi perubahan energi mekanik menjadi energi listrik (proses transduksi). Defleksi sel-sel rambut akan membuka saluran ion kalsium sehingga ion kalsium keluar 
dan merangsang vesikel untuk melepaskan neurotransmitter.

Neurotransmitter pada sinaps dan menghasilkan potensial aksi yang kemudian diteruskan ke serabut saraf delapan menuju nukleus koklearis. Impuls listrik pada nukleus koklearis akan berjalan ke nukleus olivarius homolateral dan sebagian impuls akan diteruskan ke lemniskus lateralis, kemudian menuju kolikulus inferior. Selanjutnya impuls tersebut diteruskan ke korteks auditorius yang terletak di area 41 Broadman padagirus temporalis superior.

\section{Asfiksia Perinatal}

Asfiksia perinatal didefinisikan sebagai kegagalan bernafas spontan dan teratur saat bayi lahir dan sesaat setelah lahir ditandai dengan hipoksemia, hiperkapnia dengan asidosis metabolik. Asfiksia dapat terjadi selama antepartum, intrapartum dan postpartum dengan penyebab bisa faktor ibu, faktor bayi dan faktor placenta. ${ }^{(1,22,23)}$

The American Academy of Pediatrics (AAP) dan The American College of Obstetricians and Gynecologists (ACOG) memberikan karakteristik asfiksia perinatal : ${ }^{(16)}$

1. Asidosis $(\mathrm{pH}<7.00)$,

2. Skor Apgar 0-3 menetap lebih dari 5 menit,

3. Terdapat manifestasi neurologi kejang, hipotoni, HIE, koma,

4. Didapatkan disfungsi multiorgan.

Asfiksia perinatal sebagai faktor penyebab gangguan pendengaran pada bayi dengan Apgar skor 0-4 pada 1 menit pertama, dan 0-6 pada 5 menit berikutnya. ${ }^{(6,7)}$

\section{MekanismeTerjadinyaGanggu anPendengaranPada Asfiksia}

Asfiksia menyebabkan terjadinya hiperpolarisasi sel rambut dalam yang dapat mengakibatkan perubahan pada neuron pendengaran. Menurut satu teori ${ }^{(18)}$ pelepasan spontan pada neuron pendengaran merupakan hasil dari pelepasan spontan transmiter oleh sel rambut. Dengan adanya rangsangan suara akan menyebabkan depolarisasi dari sel rambut yang akan mengakibatkan peningkatan pelepasan transmiter kimia dan loncatan saraf.

Pada asfiksia akan terjadi hiperpolarisasi dari sel rambut yang akan mengakibatkan penurunan jumlah transmiter yang dilepaskan dan berakibat penurunan dari aktivitas
saraf. $^{(18,19)}$

Jiang dkk. menjelaskan mekanisme cedera neuronal sekunder pada hipoksia yang menyebabkan terjadinya iskemia sehingga terjadi penurunan pasokan darah ke bagian tubuh. Pada keadaan hipoksia-iskemia menyebabkan pelepasan glutamat yang berlebihan pada celah saraf sinaptik, menyebabkan gangguan pada transmisi sinaptik dan menyebabkan kerusakan permanen pada neuron. $^{(20)}$

Pada keadaan awal terjadinya hipoksia akan ada suatu autoregulasi dari tubuh untukmelindungi otak dari kerusakan. Kompensasi awal adalah adanya peningkatan aliran darah ke otak (Cerebral Blood Flow), hal ini disertai dengan redistribusi curah jantung ke organ tubuh esensial, termasuk otak, jantung, dan kelenjar adrenal. Tekanan darah (Blood Pressure) akan meningkat karena peningkatan pelepasan epinefrin. Apabila kompensasi awal gagal, aliran darah ke otak bisa menjadi tekanan-pasif, di mana waktu perfusi otak tergantung pada tekanan darah sistemik. Ketika tekan darah menurun maka aliran darah ke otak juga menurun di bawah tingkat kritis dan cedera otak sekunder dapat terjadi. ${ }^{(22)}$

Hal ini menyebabkan kegagalan energi intraseluler. Selama fase awal 
cedera otak, suhu otak menurun, dan terlebih dahulu apakah terdapat terjadi pelepasan neurotransmiter lokal, kelainan lokal pada telinga seperti seperti gamma-aminobutyric transami- kelainan kongenital.

nase acid (GABA). Perubahan ini mengurangi kebutuhan oksigen di otak untuk meminimalkan dampak dari asfiksia. Pada tingkat seluler proses kerusakan akibat hipoksia ini terus berlanjut tergantung dari lama dan keparahan hipoksia. Proses selanjutnya terjadi peningkatan pelepasan reseptor asam amino, peningkatan glutamat pada sinaps, peningkatan radikal bebas dan nitrit oksida dan proses selanjutnya akan berakibat terjadinya cytotoxic edema dan kematian sel nekrotik. ${ }^{(22)}$

Pada rekaman Auditory Brainstem Respon serial pada saat terlihat tingkat kerusakan, Hal ini diperkirakan sebagai hasil dari metabolisme energi dan apoptosis yang terganggu menyebabkan kematian sel beberapa jam atau hari setelah kejadian hipoksia. ${ }^{(20,21)}$

\section{Gambaran BERA dan OAE Pada Bayi Dengan Asfiksia} Gambaran BERA

Pemeriksaan

suatu pemeriksaan elektrofisiologik yang obyektif, non invasif untuk menilai respons sistim auditorik termasuk batang otak terhadap bunyi, sehingga dapat diketahui ambang pendengaran maupun letak lesi pada sistim auditorik tsb. ${ }^{(23)}$

Pemeriksaan BERA bisa digunakan untuk mengevaluasi status sistem pendengaran pada bayi setelah episode asfiksia perinatal dengan riwayat Apgar 5 menit kurang dari 6 dan klinis tanda-tanda iskemik hipoksia ensefalopati (Hypoxic Ischemic Encephalopathy). Pemeriksaan BERA dilakukan setelah kondisi bayi stabil. Sebelum dilakukan tes BERA diperiksa
Pada pemeriksaan BERA gelombang positif direkam selama 10 detik pertama setelah rangsangan klik. Terdiri dari gelombang I-VII pada lokasi yang spesifik. Normalnya stimulus klik akan menghasilkan respons dari sel-sel rambut koklea, dan sinyal akan bergerak sepanjang jalur pendengaran dari kompleks nukleus koklearis ke kolikulus inferior di batang otak menghasilkan gelombang gelombang I- V.

Dari penelitian yang dilakukan Misra P.K dkk, menunjukkan hasil bahwa lamanya waktu pemanjangan masa laten dan interval berhubungan dengan derajat asfiksia, terutama pada minggu pertama. Sehingga intervensi dini dapat mencegah dan mengurangi kerusakan yang permanen. ${ }^{(2,20)}$

Pada bayi dengan asfiksia perinatal pada hari ketiga semua masa laten dan interval meningkat signifikan dibandingkan kontrol normal. Setelah itu, masa laten dan interval menurun secara progresif. Pada hari ketujuh, masa laten gelombang $\mathrm{V}$ dan semua interval masih berbeda secara signifikan dari subyek kontrol. Pada hari kesepuluh dan kelima belas, semua interval menurun secara signifikan. Pada hari ke tiga puluh, semua masa laten gelombang menurun sampai dengan nilai-nilai dalam subyek kontrol normal, interval juga mendekati nilai normal, meskipun interval gelombang III-V dan I-V masih meningkat sedikit. ${ }^{(2)}$

Kelainan pada gambaran BERA yang ditemukan berhubungan erat dengan derajat asfiksia dan durasi waktu kejadian asfiksia. ${ }^{(2)}$

Dari penelitian lain disimpulkan juga bahwa kelainan gambaran BERA pada bayi baru lahir dengan asfiksia 
bersifat sementara dan kembali normal pada usia 3 bulan. Pada penelitian ini dilakukan pemeriksaan BERA terhadap 30 bayi baru lahir yang mengalami asfiksia dengan nilai apgar skor kurang dari 6 sampai 5 menit didapatkan 43,3\% terdapat beberapa kelainan pada gambaran BERA, dimana terdapat masa laten yang memanjang dari beberapa gelombang. Setelah 3 bulan kemudian dilakukan evaluasi ulang, dan didapatkan perbaikan gambaran BERA menjadi normal pada 16 kasus. $^{(2,21,23)}$

\section{Gambaran Otoaccoustic Emission (OAE)}

Skrining pendengaran pada bayi-bayi dapat dilakukan dengan baik dengan menggunakan alat emisi otoakustik, karena metoda ini: obyektif, aman, tidak memerlukan prosedur yang invasif atau pengobatan sebelum dilakukan pemeriksaan, pemeriksaannya cepat, hanya memerlukan waktu beberapa detik sampai menit; caranya mudah, tidak memerlukan keahlian khusus, biaya alat yang relatif murah. $^{(21,24,25)}$

Hasil pemeriksaan mudah dibaca karena dinyatakan dengan kriteria pass (lulus) atau refer (tidak lulus). Hasil Pass menunjukkan keadaan koklea baik, sedangkan hasil refer artinya adanya gangguan koklea sehingga dibutuhkan pemeriksaan lanjutan berupa AABR atau BERA pada usia 3 bulan. Hasil OAE dipengaruhi oleh gangguan atau adanya sumbatan pada liang telinga dan kelainan pada telinga tengah (misalnya cairan). ${ }^{(25,26)}$

Untuk skrining pendengaran, digunakan OAE skrining (OAE screener) yang memberikan informasi kondisi koklea pada 4 - 6 frekuensi. Sedangkan untuk diagnostik digunakan OAE yang mampu memeriksa lebih banyak lagi frekuensi tinggi. ${ }^{(25)}$
Suatu penelitian dengan Distortion product otoacoustic emissinos (DPOAEs) terhadap bayi dengan asfiksia memberikan gambaran bahwa terdapat gangguan pada fungsi koklea bayi dengan asfiksia perinatal terutama pada frekuensi $1-5 \mathrm{kHz}$ yang terdeksi pada hari ketiga sampai lima kelahiran, dan terdapat perbaikan pada usia 1 bulan. ${ }^{(27)}$

Penelitian inidilakukan pada 46 bayi baru lahir yang mengalami asfiksia perinatal untuk mengidentifikasi frekuensi yang dipengaruhi asfiksia perinatal. Pada hari ke tiga sampai hari kelima kelahiran, di dapatkan hasil pass pada $\mathrm{f}_{2}$ nada utama di frekuensi antara 1 dan $10 \mathrm{kHz}$, sedangkan pada frekuensi 1-5 $\mathrm{kHz}$ didapatkan penurunan dibandingkan pada bayi yang tidak mengalami asfiksia perinatal. Pada usia 1 bulan dilakukan pemeriksaan ulang didapatkan hasi pass pada hampir semua frekuensi, meskipun pada frekuensi 1-2 $\mathrm{kHz}$ masih terdapat sedikit penurunan. ${ }^{(27)}$

Dari suatu penelitian lain yang dilakukan di RSUP Dr. Sardjito pada bayi baru lahir dengan asfiksia yang dirawat pada periode Januari-Juni 2011 didapatkan pemeriksaan emisi otoakustik dari 31 bayi baru lahir dengan asfiksia tanpa penyulit lain adalah pass bilateral pada 15 bayi $(48,39 \%)$ dan refer baik bilateral maupun unilateral sebanyak 16 bayi $(51,61 \%) .{ }^{(28)}$

\section{TatalaksanaAsfiksia Perinatal dan akibat yang ditimbulkan \\ Dari pemeriksaan BERA dan}

OAE didapatkan gangguan pada fungsi pendengaran di periode awal bayi baru lahir dengan riwayat asfiksia, dan didapatkan perbaikan pada usia 1 bulan. Disini sangat penting manajemen pada bayi dengan asfiksia perinatal untuk mencegah kerusakan otak yang lebih lanjut akibat terjadinya hypoxic- 
ischemic encephalopathy, baik manajemen secara farmakologi maupun non farmakologi. ${ }^{(27,29,30)}$

Salah satu manajemen asfiksia perinatal non farmakologi saat ini adalah dengan metode hipotermi. Walaupun belum dapat didefinisikan secara pasti, teknik hipotermi dapat melindungi kerusakan neuron otak dengan mengurangi tingkat metabolisme serebral, mengurangi pelepasan asam amino (glutamat, dopamin), menurunkan produksi nitrat oksida beracun dan radikal bebas. ${ }^{(29,30)}$

Teknik hipotermi dilakukan dengan menempatkan bayi pada selimut pendingin yang dengan cepat menurunkan suhu tubuh sekitar 33 derajat Celcius. Bayi didinginkan selama 72 jam dan kemudian secara bertahap kembali dihangatkan sampai suhu tubuh normal. Selama proses hipotermi, kondisi bayi selalu dipantau dengan amplitudo terintegrasi electro encephalo gram (aEEG), pemeriksaan neurologis serial, laboratorium dan studi pencitraan sebelum, selama dan setelah prosedur. Teknik hipotermi ini hanya dapat dilakukan dalam waktu enam jam setelah kelahiran dan sebaiknya sesegera mungkin. ${ }^{(31)}$

Pada gangguan pendengaran sensorineural yang menetap dan cukup berat harus dilakukan habilitasi berupa amplifikasi pendengaran, misalnya dengan alat bantu dengar (ABD). Disamping pemberian alat bantu dengar juga diperlukan habilitasi wicara berupa terapi wicara atau terapi audioverbal (AVT) sehingga anak dapat belajar mendeteksi suara dan memahami percakapan agar mampu berkomunikasi dengan optimal.

American Joint Committee on Infant Hearing (JCIH) merekomendasikan bahwa bila skrining pendengaran pada bayi telah dimulai pada usia 2 hari, kemudian diagnosis dipastikan pada usia 3 bulan sehingga habilitasi yang optimal dapat dimulai pada usia 6 bulan; maka pada usia 36 bulan diharapkan kemampuan wicara anak hampir sama dengan anak yang memiliki pendengaran normal. ${ }^{(8)}$

Pemasangan $A B D$ harus berdasarkan seleksi ABD yang tepat dan proses fitting yang sesuai dengan kebutuhan sehingga diperoleh amplifykasi yang optimal. Proses fitting ABD pada bayi/anak jauh lebih sulit dibandingkan orang dewasa. Akhirakhir ini ambang pendengaran yang spesifik pada bayi dapat ditentukan melalui teknik Auditory Steady State Response (ASSR), yang hasilnya dianggap sebagai prediksi audiogram, sehingga proses fitting ABD bayi lebih optimal. Bila ternyata ABD tidak dapat membantu, salah satu alternatif adalah implantasi koklea.

\section{KESIMPULAN}

- Asfiksia perinatal merupakan salah satu faktor resiko gangguan pendengaran pada anak.

- Asfiksia menyebabkan terjadinya hiperpolarisasi sel rambut dalam yang mengakibatkan penurunan jumlah transmiter yang dilepaskan sehingga terjadi penurunan aktivitas saraf. Asfiksia juga mengakibatkan peningkatan glutamat dan gangguan proses apoptosis.

- Kelainan gambaran BERA pada bayi dengan asfiksia perinatal adalah terjadinya peningkatan masa laten dan interval gelombang, kelainan ini dapat bersifat sementara atau menetap tergantung dari derajat asfiksia dan durasi waktu kejadian asfiksia

- Dari pemeriksaan dengan DPOAEs didapatkan gangguan pada fungsi koklea bayi dengan asfiksia perinatal terutama pada frekuensi $1-5 \mathrm{kHz}$ yang terdeksi pada hari ke 
tiga sampai lima kelahiran, dan terdapat perbaikan pada usia 1 bulan.

- Manajemen pada bayi dengan asfiksia perinatal sangat penting untuk mencegah kerusakan otak yang lebih lanjut akibat terjadinya hypoxic-ischemic encephalopathy baik secara farmakologi maupun non farmakologi.

- Salah satu manajemen asfiksia perinatal saat ini adalah dengan metode hipotermi yang dapat melindungi kerusakan neuron otak dengan mengurangi tingkat metabolis meserebral, mengurangi pelepasan asam amino (glutamat, dopamin), menurunkan produksi nitratoksida beracun dan radikal bebas.

- Pada gangguan pendengaran sensorineural yang menetap dan cukup berat harus dilakukan rehabilitasi berupa amplifikasi pendengaran, misalnya dengan alat bantu dengar (ABD), bila ternyata ABD tidak dapat membantu, salah satu alternative adalah implantasikoklea.

\section{KEPUSTAKAAN}

1. Majeed R, Memon Y, Majeed F, Shaikh NP, Rajar UDM. Risk factors of birth asphyxia. J Ayub Med Abbottabad 2007: 19(3): 6771.

2. Misra P.K, Katiyar C.P, Kapoor R.K, Shukla R, Malik G.K, et al. Brainstem auditory evoked reponse in neonates with birth asphyxia. Indian Pediatrics 1997: 34:199-204.

3. Golighltly TH, Raz S, Sander CJ. Influence of slight to moderate risk for birth hypoxia on acquisition of cognitive and language function inthe preterm infant. Neuropsycology $2003: 17(1) 3-13$.

4. Hall JG. On the neuropathological changes in the central nervous system following neonatal asphyxia with special reference to the auditory system in man. Acta Otolaryngol. 1964 Supplemen.188.

5. Wu YW, Backstrand $\mathrm{KH}$, Zhao S, Fullerton HJ, Johnston SC. Declining diagnosis of birth asphyxia in California: 1991-2000. Pediatrics 2004;114; 584.

6. Rajendran V, Roy FG. An overview of motor skill performance and balance in hearing impaired children. Journal of Pediatrics 2011 $37: 33$.

7. Taghdiri MM, Eghbalian F, Emami $\mathrm{F}$, Abbasi b, Zandevakili $\mathrm{H}$, et al. Auditory Evaluation of high risk newborn by automated auditory brain stem response. Iran J Pediatr 2008: 18(4): 330-4.

8. Joint committee on infant hearing. Principles and guidelines for early hearing detection and intervention programs. Pediatrics 2007;120; 898.

9. Grill E, Hessel F, Siebert U, Schnell $\mathrm{P}$, Kunze s, et al. Comparing the clinical effectiveness of different new-born hearing screening strategies. A decision analysis. BMC public health 2005:5:12.

10. Hill M. Development of the organs of audition and equilibrium inner ear. UNSW Embryology. 2010.

11. Glowatzki E. Afferent synaptic transmission by cochlear hair cells 
structure and function. Johns Hopkins School of Medicine;2011.

12. Brown MC, Nuttall AL, Masta RI, Lawrence M. Cochlear inner hair cells: Effects of transient asphyxia on intracellular potentials. Hearing Research 1983: 9:131-44.

13. Alberti PW. The anatomy and physiology of the ear and hearing. WHO international. 2001 (2):55-62.

14. Mills JH, Khariwala S, Weber PC, Anatomy And Physiology of Hearing. In: Bailey BJ, Johnson JT, editors. Head and Neck Surgery Otolaryngology, $4^{\text {th }}$ ed. Lippincott Williams\&Wilkins Publisers; 2006. p.1883-903.

15. Austin Df. Anatomy of the Ear. In: Ballenger JJ, Snow JB, editors. Otorhinolaryngology head and neck surgery, $15^{\text {th }}$ ed. Baltimore: Williams \& Wilkins;1996. p. 83857.

16. American Academy of Pediatrics. The Apgar Score. The American college of obstetrician and gynecologists. 2006: 117(4); 14447.

17. Lincetto O. Birth asphyxiasummary of the previous meeting and protocol overview. World Health Organization Geneve;2007.

18. Davis H, Fernandez C, McAuliffe D.R. The axcitatory process in the cochlea. Central institute for the deaf, St. Louis, Missouri. 1950; 36; 580-7.

19. Kim D.O, Molnar C.E. A population study of cochlear nerve fibers: Comparison os spatial distributions of average-rate and phase-locking measures of responses to single tones. Journal of Neurophysiology. 1979; 42(1): 1630.

20. Jiang ZD, Brosi DM, Wang J, Xu, Chen GQ, Shao XM, et al. Time course of brainstem pathophysiology during first month in term infants after perinatal asphyxia, revealed by MLS BAER latencies and intervals. Pediatric Research. 2003, 54(5): 680-87.

21. Davies LM. Effects of perinatal hypoxia on frequency-specific auditory brainstem responses in the chick (dissertation). James Madison University: 2009.

22. American Academy of Pediatrics. Relation between perinatal factors and neurological outcome. In: Guidelines for Perinatal Care. 3rd ed. Elk Grove Village, Ill: American Academy of Pediatrics; 1992: 22134.

23. Jiang ZD, Brosi DM, Shao XM, Wilkinson AR. Sustained depression of brainstem auditory electrophysiology during the first month in term infants after perinatal asphyxia. Clinical Neurophysiology. 2008, 119: 1496-505.

24. Watkin. Outcomes of neonatal screening for hearing loss by otoacoustic emission. Archives of Disease in Childhood 1996, 75:15868.

25. Hall JW. A guide to otoacoustic emissions for otolaryngologists. Maico diagnostic : 2009. 
26. Kemp DT. Otoacoustic emissions, 29. Jacobs SE, Mordi WO. Therapeutic their origin in cochlear function, and use. British Medical Bulletin 2002: 63: 223-41. hypothermia for newborn infants with hypoxic-ischaemic encephalopathy. Journal of Paediatrics and Child Health 2010.

27. Jiang ZD, Zhang Z, Wilkinson AR. 46: 568-76.

Distortion product otoacoustic emissions in term infants after 30. Polin RA, Randis TM, Sahni R. hypoxia-ischaemia. Eur $\mathrm{J}$ Pediatr 2005 : 164: 84-87.

28. Sudarman K, Hakim L. Gambaran OAE pada bayi dengan riwayat asfiksia di RSUP Dr. Sarjito periode Januari 2011-2011. Bagian Ilmu Kesehatan THT-KL FK UGM /RSUP Dr. Sardjito Yogyakarta. Systemic hypothermia to decrease morbidity of hypoxic-ischemic brain injury. Journal of Perinatology 2007. 27: 47-58.

31. Hansen A, Soul J. New induced hypothermia protocol. Pediatric Views; $\quad$ February 2008. 2011. 